\title{
Impact of gibberelic acid and tebuconazole on formation of the leaf system and functioning of donor - acceptor plant system of solanaceae vegetable crops
}

\author{
V. H. Kuryata, V. V. Rogach, O. I. Buina, O. V. Kushnir, O. V. Buinyi \\ Mykhailo Kotsiubynskyi Vinnytsia State Pedagogical University, Vinnytsia, Ukraine
}

Article info

Received 21.03.2017

Received in revised form 25.04.2017

Accepted 29.04.2017

Mykhailo Kotsyubynskiy Vinnitsya State Pedagogical University, Ostrozhskogo Str., 32, Vinnitsa, 21000, Ukraine. Tel: $+38-098-59-44-832$ E-mail:rogachv@ukr.net

Kuryata, V. H., Rogach, V. V., Buina, O. I., Kushnir, O. V., \& Buinyi, O. V. (2017). Impact of gibberelic acid and tebuconazole on formation of the leaf system and functioning of donor - acceptor plant system of solanaceae vegetable crops. Regulatory Mechanisms in Biosystems, 8(2), 162-168. doi:10.15421/021726

We studied the comparable effect of gibberelic acid and tebuconazole on morphogenesis, mesostructure formation and redistribution of flows in sweet peppers and tomatoes. It has been found that the use of gibberelic acid and tebuconazole retardant during budding leads to increased plant productivity due to optimization of the structure and operation of the plants' leaf apparatus. It was established that both gibberelic and antigibberelic tebuconazole drug stimulated the formation and functioning of the photosynthetic apparatus of peppers and tomatoes, but the mechanisms of this regulation were different. Increased photosynthetic activity of plants under the influence of gibberellin was determined primarily by the formation of more leaves and total leaf surface. When using tebuconazole retardant there was a significant restructuring of the organization of leaf mezostructure: the leaves were thickened by chlorenchyma proliferation, there was an increase in the volume of columnar parenchyma cells and linear dimensions of spongy parenchyma leaf cells. The surface density of leaves significantly increased, the chlorophyll content and nitrogen content (especially protein) also increased, compared with control variants and variants using gibberelin. Such a profound restructuring of the photosynthetic apparatus in plants under the actions of tebuconazole led to a significant increase in donor leaves function of peppers and tomatoes, which is an indicator of the growth of net productivity of photosynthesis - the highest among all the variants of the experiment. The results also show that increasing the chlorophyll phytocenotic index was more significant than the increase of leaf index: the tomatoes under the actions of tebuconazole had a lower leaf index than in control options, but due to a higher chlorophyll index the crop productivity increased.Since during the fruiting period the costs of assimilates to the growth of vegetative organs are greatly reduced, optimization of photosynthetic apparatus in pepper and tomato plants led to the laying of more fruit per plant and increasing crop yield. The analysis of the mass ratio of the researched vegetative and fruit plants shows that the mass fraction of fruit (an acceptor sphere of plants during fruiting) under the action of both drugs increased. Thus in both variants of the experiment both the mass fraction and donor assimilates of leaves was higher. Apart from the main source of assimilates - the processes of photosynthesis, which intensified due to the formation of a larger area of leaf surface (variant with gibberelin) or optimization of mesostructure (variant with tebuconazole) it is probable that the formation and growth of the embryo occurred in part due to reutilization of carbohydrates from the vegetative plant organs in carpogenesis processes.

Keywords: donor - acceptor system; gibberellins; retardants; photosynthesis; Capsicum annuum L.; Lycopersicum esculentum $\mathrm{L}$.

\section{Вплив гіберелової кислоти та тебуконазолу на формування листкового апарату та функціонування донорно-акцепторної системи рослин овочевих пасльонових культур}

\author{
В. Г. Кур’ята, В. В. Рогач, О. І. Буйна, О. В. Кушнір, О. В. Буйний \\ Вінниџький державний педагогічний університет імені Михайла Коџюбинського, Вінниия, Украйна
}

\footnotetext{
Оцінено вплив гіберелової кислоти та тебуконазолу на морфогенез, формування мезоструктури та перерозподіл потоків асимілятів у рослинах перцю солодкого та томату їстівного. Застосування у період бутонізації гіберелової кислоти та тебуконазолу викликає підвищення продуктивності культур внаслідок оптимізації структури та функціонування їх листкового апарату. Як гіберелін, так і антигібереліновий препарат тебуконазол стимулювали формування та функціонування фотосинтетичного апарату перцю та томатів, однак шляхи цієї регуляції різні. Посилення фотосинтетичної активності рослин за впливу гібереліну визначалося в першу чергу формуванням більшої кількості листків і загальної площі листкової поверхні. Застосування тебуконазолу зумовлювало суттєву перебудову мезоструктури листків, їх потовщення за
} 
рахунок розростання хлоренхіми, збільшення об'єму клітин стовпчастої паренхіми та лінійних розмірів клітин губчастої паренхіми листків. При цьому підвищувалася питома поверхнева щільність листків, суттєво зростав уміст хлорофілів та вміст азоту (у першу чергу білкового) порівняно 3 контролем і варіантом із застосуванням гібереліну. Така глибока перебудова фотосинтетичного апарату рослини за дії тебуконазолу спричинювала суттєве зростання донорної функції листків перцю та томатів, показником чого є зростання чистої продуктивності фотосинтезу - найвищої серед усіх варіантів досліду. Отримані результати свідчать також про те, що збільшення хлорофільного індексу виявилося вагомішим фактором, ніж збільшення листкового індексу: у томатів за дії тебуконазолу листковий індекс був нижчим, ніж у контролі, однак завдяки вищому хлорофільному індексу урожайність насаджень збільшилася. Оскільки у період плодоношення витрати асимілятів на ріст вегетативних органів суттєво зменшуються, оптимізація фотосинтетичного апарату рослин перцю та томатів сприяла закладанню більшої кількості плодів на рослині та підвищенню урожайності культур. Аналіз співвідношення мас вегетативних органів і плодів дослідних рослин свідчить, що масова частка плодів (акцепторна сфера рослини під час плодоношення) за дії обох препаратів зросла. При цьому в обох варіантах досліду вищою була також масова частка донорів асимілятів - листків. Крім основного джерела асимілятів - процесів фотосинтезу, які посилювалися внаслідок формування більшої площі листкової поверхні (варіант із гібереліном), або оптимізації мезоструктури (варіант із тебуконазолом), формування та ріст плодів відбувалися, імовірно, частково за рахунок реутилізації вуглеводів із вегетативних органів рослини на процеси карпогенезу.

Ключові слова: донорно-акцепторна система; гіберелін; ретардант; фотосинтетичний апарат; Capsicum annuиm L.; Lycopersicum esculentum L.

\section{Ветуп}

Важливе завдання сучасної фітофізіології - розроблення методів і технологій, які б забезпечили повніше використання рослиною енергії світла для інтенсифікації синтезу асимілятів та спрямування їх до господарсько цінних тканин і органів. Один із ключових підходів до вирішення питання оптимізації продукційного процесу сільськогосподарських рослин - регуляція донорно-акцепторних відносин, зокрема, шляхом перерозподілу потоків асимілятів до господарсько важливих органів (плодів, коренеплодів тощо). Основні закономірності функціонування донорно-акцепторних відносин (концепції "sourcesink") вивчаються під час аналізу співвідношення інтенсивності росту та фотосинтезу, де процеси росту виступають як основний акцептор, а фотосинтез - як донор асимілятів (Rogach and Rogach, 2015; Yu et al., 2015; Kuryata et al., 2016; Rogach et al., 2016). Регуляція ростових процесів - один із дієвих засобів підвищення урожайності сільськогосподарських культур шляхом змін донорно-акцепторних відносин у рослині (Poprotska and Kuryata, 2017), поліпшення якості аграрної продукції (Kuryata and Hodanic'ka, 2012) та підвищення стійкості культурних рослин до несприятливих абіотичних та біотичних чинників середовища завдяки мобілізації потенційних можливостей рослинного організму (Khan et al., 2012; Tae-Yun and Jung-Hee, 2012; Matysiak and Kaczmarek, 2013; Muhammad and Muhammad, 2013; Saeidi-Sar et al., 2013; Yang et al., 2016).

Перспективний напрям регуляції ростових процесів - застосування нативних фітогормонів та синтетичних регуляторів росту - аналогів або модифікаторів дії фітогормонів. Із практичною метою широко застосовують рістстимулювальні гіберелінові препарати (Ribeiro et al., 2012; Wang et al., 2013; Poprotska and Kuryata, 2017), а також їх антагоністи - ретарданти, які блокують синтез або утворення гормон-рецепторного комплексу, внаслідок чого зменшується інтенсивність лінійного росту рослин (Ribeiro et al., 2012; Rogach et al., 2016). У літературі міститься інформація про застосування гібереліну та антигіберелінових препаратів із метою оптимізації продукційного процесу шляхом анатомо-морфологічних та фізіологобіохічіних змін у зерново-круп'яних (Muhammad and Muhammad, 2013; Wang et al., 2016; Yang et al., 2016), зернобобових (Saeidi-Sar et al., 2013; Yan et al., 2013; Golunova, 2015; Yan et al., 2015), олійних (Kuryata and Hodanic'ka, 2012; Kumar et al., 2013; Matysiak and Kaczmarek, 2013; Kuryata and Polyvanyj, 2015), овочевих (Khan et al., 2012; Tae-Yun and JungHee, 2012; Pavlista, 2013; Tkachuk, 2015), технічних (Mohammad and Mohammad, 2013), лікарських і декоративних (Zhang et al., 2013; Sardoei et al., 2014; Sugiura et al., 2015) культур.

Нативні гормони-стимулятори та їх синтетичні аналоги застосовують у рослинництві з метою інтенсифікації гісто- та морфогенезу, прискорення проліферації та диференціації клітин, внаслідок чого формується розгалужена коренева система, змінюються анатомо-морфологічні, мезоструктурні та фізіолого-біохімічні особливості листка. Такі зміни зумовлюють формування потужного асиміляційного апарату, здатного забезпе- чити активний синтез пластичних сполук, потік яких у більшій кількості буде спрямований до генеративних органів (Kuryata and Poproc'ka, 2016; Poprotska and Kuryata, 2017). Дія гіберелінів пов'язана з підвищенням активності різних груп меристематичних тканин і формуванням потужнішого рослинного організму, внаслідок посилення поділу та розтягування клітин (Rogach and Rogach, 2015). Крім цього гібереліни затримують старіння листків та індукують закладання більшої кількості квіток на рослині.

Sugiura et al. (2015) показали, що гіберелова кислота збільшує біомасу листя та активізує фотосинтетичні процеси у Polygonum cuspidatum. Гіберелова кислота сприяє накопиченню сухої речовини рослинами льону, зростанню чистої продуктивності фотосинтезу, збільшенню урожайності насіння, підвищенню його олійності та виходу волокон (Mohammad and Mohammad, 2013). Цей самий препарат підвищує стійкість проростків звичайних бобів (Saeidi-Sar et al., 2013), пшениці (Muhammad and Muhammad, 2013), pису (Khan et al., 2012; Wang et al., 2013) та огірка (Khan et al., 2012) до засолення, підвищує їх продуктивність.

Перебудова гормонального комплексу за впливу ретардантів та відповідне інгібування апікального домінування спричиняли важливе з погляду регулювання продуктивності рослин посилення галуження стебла. Завдяки посилення галуження стебла цих культур закладається більша кількість листків, квітів і плодів. Застосування хлормекватхлориду на рослинах сої зумовило гальмування ростових процесів, що спричинило закладання більшості кількості плодів, підвищення вмісту олії та поліпшення іiі якості (Golunova, 2015). Yan et al. (2013) встановили, що уніконазол одночасно з гальмуванням лінійних розмірів рослин зумовлює посилення розвитку кореневої системи. Обробка насіння сої цим препаратом окрім гальмування росту зумовила затримання процесів старіння листків, збільшення маси сухої речовини рослин і показника чистої продуктивності фотосинтезу. Одночасно препарат збільшує вміст хлорофілу в листках, зменшує площу листя та підвищує урожайність культури (Yan et al., 2015). Оптимізацію фотосинтетичних процесів під час гальмування росту рослин вігни спостерігали за впливу ССС та ГМК (Sukul et al., 2014). Тебуконазол гальмує ріст рослин кукурудзи, але підвищує схожість та стійкість рослин до холодового стресу. За дії препарату зростає вміст фотосинтетичних пігментів у листках культури (Yang et al., 2016). Суміш етиленпродуценту DCPTA та четвертинної амонієвої солі ССС зменшує висоту рослин за рахунок зменшення довжини міжвузлів. Суміш антигіберелінових препаратів збільшує також площу листя та масу сухої речовини листків, вміст у них хлорофілу. Такі зміни сприяли підвищенню продуктивності культури (Wang et al., 2016).

Інгібітори гібереліну також широко застосовують на олійних культурах. Для озимого ріпаку негативним $є$ надмірний розвиток вегетативної маси восени, що погіршує перезимівлю культури та зменшує іï продуктивність на наступний рік. Обробка культури озимого ріпаку тебуконазолом і флуцілазолом зменшує швидкість ростових процесів та приріст вегетативної маси з одночасним збільшенням урожайності насіння, 
причому вміст олії в насінні та іï якісні характеристики не змінюються (Matysiak and Kaczmarek, 2013). Застосування паклобутразолу зменшує висоту рослин, площу їх листя, але збільшує вміст хлорофілу в листках і врожайність насіння за рахунок посилення галуження стебла та збільшення кількості стручків (Kumar et al., 2012). Обробка маку олійного фолікуром на фоні зменшення лінійних розмірів рослин позитивно впливає на показники листкового апарату рослин. Автори встановили зростання кількості листків на рослині, їх маси та площі листкової поверхні. За дії ретарданту зростає вміст хлорофілу в листках, підвищується чиста продуктивність фотосинтезу, одночасно поліпшуються ценотичні показники посівів (листковий і хлорофільний індекси). Зміни листкового апарату стали передумовою підвищення урожайності культури (Kuryata and Polyvanyj, 2015). Подібні зміни листкового апарату зафіксовано в льону олійного у разі застосування хлормекватхлориду. Ретардант зменшував лінійні розміри рослин, потовщував стебло, збільшував кількість листків, масу їх сухої речовини та площу листя. Хлормекватхлорид збільшував об'єм клітин стовпчастої паренхіми листка та розміри клітин губчастої паренхіми, а також збільшував кількість і об'єм хлоропластів обох тканин хлоренхіми. За дії препарату зростала чиста продуктивність фотосинтезу, збільшувалася урожайність насіння та вихід олії із нього, поліпшувалися якісні характеристики олії (Kuryata and Hodanic'ka, 2012). Аналогічні зміни зафіксовані у разі застосування інгібіторів росту ретардантнтного типу також на інших олійних сільськогосподарських культурах (Kuryata and Poproc'ka, 2016).

Літературні джерела містять інформацію про вплив ретардантів на листковий апарат і продуктивність лікарських і декоративних рослин. Зокрема, хлорхолінхлорид збільшував фотосинтетичну активність листків гінкго дволопатевого за рахунок зростання вмісту хлорофілу у листках; також зростав вміст розчинних цукрів i амінокислот, що поліпшувало якість сировини, iii лікувальні властивості (Zhang et al., 2013). Цей самий препарат змінював активність накопичення вуглеводів листками рослин коноплі (Sardoei et al., 2014). У рослин пуансетії флурпірамідол зменшував лінійні розміри та збільшував вміст хлорофілу в листках (Pobudkiewicz, 2014). Інший триазолпохідний препарат - уніконазол - на фоні зменшення біомаси листків рослин Polygonum cuspidatum збільшував відношення біомаси до площі листкової поверхні (Sugiura et al., 2015).

Овочеві культури мають велике господарське значення, тому вивчення процесів регуляції їх росту та розвитку за допомогою антигіберелінових препаратів та гібереліну - актуальне питання сучасної фізіології рослин. Дані літератури свідчать, що обробка картоплі паклобутразолом зменшує лінійні розміри пагона та потовщує його. Препарат зменшує площу листя, але збільшує товщину листків та масу їх сирої та сухої речовини. За дії паклобутразолу поліпшується мезоструктурні показники листка - об'єм клітин стовпчастої паренхіми та розміри клітин губчастої паренхіми. Застосування препарату зумовило зростання чистої продуктивності фотосинтезу та урожайності культури (Tkachuk, 2015). Урожайність картоплі також зростає після обробки CCC (Pavlista, 2013). В іншої бульбової культури - маніоки їстівної - паклобутразол зменшує висоту рослин та листковий індекс, але збільшує масу сухої речовини цілої рослини за рахунок зростання маси бульб. За дії препарату у цієї тропічної культури зростає вміст крохмалю у бульбах (Panyapruek et al., 2016). В огірків інший триазолпохідний ретардант - гексаконазол - зменшує довжину стебла, масу його сирої та сухої речовини, площу листя, але збільшує товщину листкових пластинок, вміст хлорофілу в них та підвищує стійкість культури до дії ультрафіолетового опромінення за рахунок активізації антиоксидантних ферментів та збільшення вмісту аскорбінової кислоти у листках (Tae-Yun and Jung-Hee, 2012).

Ми встановили підвищення врожайності за дії різнонаправлених регуляторів росту в овочевих культур роду Solanum.
Зокрема, обробка гібереловою кислотою та антигібереліновими препаратами тебуконазолом і хлормекватхлоридом позитивно впливає на листковий апарат рослин картоплі та баклажанів, що оптимізує продуктивність цих культур (Rogach and Rogach, 2015; Kuryata et al., 2016; Rogach et al., 2016).

Отже, численні дані літератури свідчать, що екзогенно застосовані гібереліни та їх антагоністи (ретарданти) достатньо часто викликають один і той самий результат - оптимізацію продукційного процесу сільськогосподарських культур і підвищення їх урожайності. Разом із цим, у літературі практично відсутні системні дослідження регуляції швидкості росту, морфогенезу, формування фотосинтетичного апарату за дії гібереліну та антигіберелінових препаратів, залишаються невстановленими складові системи регуляції донорно-акцепторних відносин у рослинах за дії цих різнонаправлених препаратів.

У зв'язку з викладеним, мета цього дослідження - встановити роль морфологічної та мезоструктурної складових у регуляції донорно-акцепторних відносин рослин томатів і перців за дії гіберелової кислоти та антигіберелінового препарату тебуконазолу.

\section{Матеріал і методи досліджень}

Польові дрібноділянкові досліди закладали на землях СФГ «Бержан П. Г.» (с. Горбанівка Вінницького району Вінницької області) у вегетаційні періоди 2013-2015 років. Розсаду перців сорту Антей висаджували стрічковим способом за формулою $80+50+50 \times 25$, а томатів сорту Бобкат $-80+50+50 \times 50$. Вносили мінеральні добрива $\mathrm{N}_{50} \mathrm{P}_{40} \mathrm{~K}_{30}$. Площа ділянок $-33 \mathrm{~m}^{2}$, повторність - п'ятикратна. Рослини обробляли вранці за допомогою ранцевого оприскувача ОП-2 до повного змочування листків 0,025\% розчином тебуконазолу (EW-250) та 0,005\% розчином гіберелової кислоти $\left(\Gamma_{3}\right)$ у фазу бутонізації 17.07.2013, 10.07.2014 i 19.07.2015 p. - перців, 14.06.2013, 17.06.2014 i 19.06.2015 р. - томатів. Контрольні рослини обприскували водопровідною водою. Фітометричні показники (висота рослин, маса сухої та сирої речовини рослини та листя, площа листків) визначали на 20 рослинах. Матеріали для вивчення мезоструктурної будови листка відбирали у фазу утворення плодів. Мезоструктуру листків дослідних рослин вивчали на фіксованому матеріалі. Для його консервації застосовували суміш рівних частин етилового спирту, гліцерину, води 3 додаванням 1\% формаліну. Визначення розмірів клітин хлоренхіми та ії̈ товщину здійснювали за допомогою мікроскопа Микмед-1 та окулярного мікрометра МОБ-1-15x у 35кратній повторності. Для мезоструктурного аналізу відбирали листки середнього ярусу. У фазу плодоношення визначали вміст суми хлорофілів у свіжому матеріалі спектрофотометричним методом на спектрофотометрі СФ-16, вміст цукрів i крохмалю, вміст різних форм азоту у фіксованому та висушеному матеріалі у п'ятикратній аналітичній повторності (Bala et al., 2013). Протягом вегетації визначали чисту продуктивність фотосинтезу (ЧПФ) як приріст маси сухої речовини за одиницю часу на одиницю площі листків, індекс листкової поверхні (ЛІ) як відношення сумарної площі листків до одиниці площі насаджень і хлорофільний індекс (XI) як добуток площі листків рослини та вмісту сумарного хлорофілу в них.

У таблицях і на графіках наведено середні дані за три роки досліджень. Результати обробляли статистично за допомогою комп'ютерної програми Statistica 6.0 (StatSoft Inc., USA). Застосовували однофакторний дисперсійний аналіз, відмінності між середніми значеннями вважали вірогідними за $\mathrm{P}<0,05$ (Van Emden, 2008). У таблицях наведено середні арифметичні значення та їх стандартні похибки (SE).

\section{Результати}

Антигіберелінові препарати тебуконазол гіберелова кислота зумовили зміни морфогенезу та продуктивності рослин тома- 
тів сорту Бобкат і перців сорту Антей. Зокрема, застосування ретарданту зумовило зменшення лінійних розмірів рослин перців і томатів у фазу формування плодів (відповідно на $18 \%$ та $16 \%$ протягом різних років досліджень). За дії гіберелової кислоти ріст відбувався активніше, висота рослин перевищувала контрольний показник на $12 \%$ та 16\% відповідно (табл. 1).

Зміна темпів ростових процесів за впливу регуляторів росту супроводжувалася змінами будови, розмірів і функціонування вегетативних і генеративних органів. Установлено зміни листкового апарату дослідних рослин. За обробки гібереловою кислотою рослин томатів і перцю зростала кількість листків на рослині, середня маса сухої та сирої речовини листків. Обробка тебуконазолом зумовила достовірне зростання маси сирої та сухої речовини у рослин перців за зменшення загальної кількості листків. У томатів за дії ретарданту збільшилася маса сирої та сухої речовини листків, збільшилась кількість листків.

Площа листя - один $з$ основних морфологічних показників, що суттєво впливає на продуктивність сільськогосподарських культур. Обробка гібереловою кислотою достовірно збільшує цей показник у рослин перців і томатів. Антигібереліновий препарат тебуконазол збільшує площу листя рослин перців і практично не змінює у томатів. Збільшення площі листкової поверхні у перців відбувається за рахунок збільшення площі окремих листків, оскільки загальна їх кількість за дії препарату зменшилася.

Кількісна характеристика фотосинтетичних процесів - питома поверхнева щільність листка. Тебуконазол суттєво збільшує цей показник у рослин перців (на $61 \%$ ) і томатів (на 23\%). Аналогічні результати отримано для інших культур (Kuryata and Poproc'ka, 2016). За дії гіберелової кислоти цей показник порівняно $з$ контролем достовірно не змінюється.

Отримані результати свідчать про суттєву перебудову листкового апрарату за впливу гібереліну та ретарданту. У зв'язку із цим доцільно проаналізувати зміни мезоструктури листків дослід- них рослин за дії регуляторів росту різного напрямку дії. Тебуконазол суттєво потовщував листкові пластинки рослин перців і томатів за рахунок розростання клітин основної фотосинтетичної тканини - хлоренхіми, зміни товщини верхнього та нижнього епідермісу були незначними (табл. 2). Потовщення асиміляційної тканини відбувалося як за рахунок зростання об'єму клітин стовпчастої паренхіми, так і розмірів клітин губчастої. Гіберелова кислота також впливала на розвиток фотосинтетичної тканини, але не так відчутно. Вказані зміни мезоструктури листкових пластинок пасльонових культур можуть створювати передумови для підвищення їх фотосинтетичної активності.

Один 3 основних показників, що впливає на продуктивність рослин, - вміст хлорофілів у листках. Протягом вегетаційного періоду інгібітори росту збільшували концентрацію хлорофілів $(\mathrm{a}+\mathrm{b})$ у листках перців і томатів, що відмічалося раніше для інших культур (Kuryata and Polyvanyj, 2015). За дії гіберелової кислоти вміст хлорофілів зменшувався. Про позитивний вплив обох препаратів на формування фотосинтетичних структур листка свідчить підвищений вміст азоту в листках обох культур, причому дія тебуконазолу більш виражена. Важливі ценотичні показники насаджень - листковий та хлорофільний індекси. Гіберелова кислота збільшувала листковий індекс у рослин перців і томатів у фазу активного формування плодів і зменшувала хлорофільний індекс. Тебуконазол збільшував як листковий, так і хлорофільний індекси у рослин перців і хлорофільний індекс у рослин томатів.

3 погляду ефективності біологічної продуктивності дослідних рослин важливе вивчення динаміки накопичення маси сухої речовини рослинами. Обидва регулятори росту стимулюють накопичення маси сухої речовини рослинами овочевих (табл. 1). Триазолпохідний ретардант тебуконазол суттєво збільшує показник ЧПФ у період плодоношення в обох культур. При цьому за дії гібереліну зростання цього показника було значно меншим (перці), або різниця була недостовірною (томати).

\section{Таблиця 1}

Морфофізіологічні показники перців сорту Антей та томатів сорту Бобкат за дії регуляторів росту (фаза плодоношення, середні дані за 2013-2015 роки, $\mathrm{n}=20$ )

\begin{tabular}{|c|c|c|c|c|c|c|}
\hline \multirow{2}{*}{ Показник } & \multicolumn{3}{|c|}{ Перці } & \multicolumn{3}{|c|}{ Томати } \\
\hline & K & $\Gamma K_{3}$ & EW-250 & K & $\Gamma K_{3}$ & EW-250 \\
\hline Висота рослини, см & $42,4 \pm 1,08$ & $47,5 \pm 1,12^{*}$ & $34,6 \pm 1,02 *$ & $64,3 \pm 1,57$ & $74,9 \pm 1,89^{*}$ & $54,1 \pm 1,32 *$ \\
\hline Кільк & $96,5 \pm 2,44$ & $97,7 \pm 2,68$ & $86,4 \pm 2,12 *$ & $72,1 \pm 1,74$ & $89,4 \pm 2,21 *$ & $80,2 \pm 1,98^{*}$ \\
\hline човини листків, г & $36,3 \pm 0,97$ & $47,6 \pm 1,11^{*}$ & $48,4 \pm 1,32 *$ & $286,8 \pm 7,71$ & $471,3 \pm 9,93^{*}$ & $295,2 \pm 8,12$ \\
\hline Маса сухої речовини листків, г & $12,6 \pm 0,55$ & $18,2 \pm 0,81^{*}$ & $23,1 \pm 0,97 *$ & $55,5 \pm 2,14$ & $91,7 \pm 4,27 *$ & $58,2 \pm 2,02$ \\
\hline Площ & $1434 \pm 69,9$ & $1962 \pm 89,7^{*}$ & $2172 \pm 98,9^{*}$ & $10937 \pm 414,4$ & $19177 \pm 832,1^{*}$ & $9494 \pm 404,3$ \\
\hline верхнева щільність листка, мг/см² & $6,66 \pm 0,21$ & $7,05 \pm 0,28$ & $10,74 \pm 0,41^{*}$ & $4,82 \pm 0,18$ & $4,57 \pm 0,14$ & $5,92 \pm 0,22^{*}$ \\
\hline Вміст суми хлорофілів $(a+b), \%$ на масу сирої & $0,58 \pm 0,02$ & $0,54 \pm 0,02$ & $0,68 \pm 0,03 *$ & $0,58 \pm 0,03$ & $0,55 \pm 0,03$ & $0,70 \pm 0,04 *$ \\
\hline & & & & 06 & & $3,05 \pm 0,07$ \\
\hline Білко & $71 \pm 0,05$ & $3,01 \pm$ & $3,14 \pm 0,07$ & $2,37 \pm 0,05$ & $2,40 \pm 0,05$ & $2,58 \pm 0,06$ \\
\hline ої речовини рослини & $51,3 \pm 2,28$ & $66,4 \pm 3,32 *$ & $77,1 \pm 3,54 *$ & $201,8 \pm 9,19$ & $299,1 \pm 11,17^{*}$ & $218,4 \pm 10,11$ \\
\hline ЧПФ, г/(м²·доба) & $11,0 \pm 0,51$ & $13,8 \pm 0,58^{*}$ & $19,9 \pm 0,98^{*}$ & $8,81 \pm 0,38$ & $8,72 \pm 0,42$ & $12,7 \pm 0,55^{*}$ \\
\hline ЛI, $\mathrm{m}^{2} / \mathrm{M}^{2}$ & $1,49 \pm 0,061$ & $1,89 \pm 0,082 *$ & $1,91 \pm 0,084^{*}$ & $3,64 \pm 0,173$ & $6,39 \pm 0,280^{*}$ & $3,16 \pm 0,142$ \\
\hline $\mathrm{XI}, \mathrm{\Gamma} / \mathrm{M}^{2}$ & $1,92 \pm 0,08$ & $1,30 \pm 0,05^{*}$ & $2,01 \pm 0,09$ & $1,31 \pm 0,07$ & $1,17 \pm 0,05$ & $1,87 \pm 0,08^{*}$ \\
\hline
\end{tabular}

Примітка: К - контроль, ГК

Таблиця 2

Вплив регуляторів росту на мозоструктурні показники листків перців і томатів (фаза утворення плодів, $\mathrm{n}=35$ )

\begin{tabular}{|c|c|c|c|c|c|c|}
\hline \multirow{2}{*}{ Показник } & \multicolumn{3}{|c|}{ Перці } & \multicolumn{3}{|c|}{ Томати } \\
\hline & $\mathrm{K}$ & $\Gamma K_{3}$ & EW-250 & $\mathrm{K}$ & $\Gamma \mathrm{K}_{3}$ & EW-250 \\
\hline Товщина листка, мкм & $264 \pm 5,8$ & $298 \pm 6,5^{*}$ & $337 \pm 8,5^{*}$ & $239 \pm 3,2$ & $289 \pm 8,8^{*}$ & $296 \pm 9,6^{*}$ \\
\hline Товщина хлоренхіми, мкм & $217 \pm 4,7$ & $237 \pm 5,8^{*}$ & $283 \pm 7,1^{*}$ & $186 \pm 1,6$ & $242 \pm 7,7^{*}$ & $243 \pm 8,3^{*}$ \\
\hline Товщина верхнього епідермісу, мкм & $23,3 \pm 0,62$ & $31,1 \pm 0,21 *$ & $26,2 \pm 0,84 *$ & $29,2 \pm 0,81$ & $28,0 \pm 0,76$ & $31,0 \pm 0,79$ \\
\hline Товщина нижнього епідермісу, мкм & $23,9 \pm 0,49$ & $29,6 \pm 0,53 *$ & $27,8 \pm 0,51 *$ & $24,1 \pm 0,80$ & $18,8 \pm 0,41^{*}$ & $22,0 \pm 0,54 *$ \\
\hline Об’єм клітин стовпчастої паренхіми, мкм ${ }^{3}$ & $19857 \pm 896$ & $26689 \pm 1117^{*}$ & $28366 \pm 788^{*}$ & $6228 \pm 301$ & $10057 \pm 495^{*}$ & $9949 \pm 332 *$ \\
\hline Довжина клітин губчастої паренхіми, мкм & $33,3 \pm 0,95$ & $39,8 \pm 0,78^{*}$ & $40,2 \pm 0,57^{*}$ & $30,3 \pm 1,46$ & $36,1 \pm 1,25^{*}$ & $41,6 \pm 2,14 *$ \\
\hline Ширина клітин губчастої паренхіми, мкм & $24,9 \pm 0,75$ & $32,4 \pm 0,89 *$ & $31,9 \pm 0,57^{*}$ & $23,6 \pm 1,46$ & $25,5 \pm 0,59$ & $26,4 \pm 1,37$ \\
\hline
\end{tabular}

Примітка: позначення див. табл. 1.

Аналіз отриманих результатів свідчить про суттєві зміни співвідношення мас вегетативних і генеративних органів обох культур за дії препаратів (рис.). В обох культур відмічене зростання частки плодів у загальній масі рослини, у першу чергу за рахунок зменшення частки сухої речовини стебла, що свідчить про зміни характеру донорно-акцепторних відносин і 
перерозподіл асимілятів у рослині у бік плодів. При цьому масова частка листків не лише не зменшувалась, а навіть збільшувалась, - важливий показник оптимізації продукційного процесу. Аналіз отриманих даних свідчить, що протягом вегетаційного періоду в цілому відбувалося зменшення вмісту суми вуглеводів (цукри + крохмаль) у вегетативних органах рослин, причому найсуттєвіші зміни відбувалися у стеблі рослин перців і томатів (табл. 3). Дія тебуконазолу сильніша саме в цьому варіанті: в обох культур вміст вуглеводів у стеблі був мінімальним. Отже, у період плодоношення за впливу застосованих регуляторів росту посилений ріст плодів визначається інтенсивним перерозподілом асимілятів на процеси карпогенезу.

Зміна швидкості ростових процесів у рослин перців і томатів і зумовлена цим зміна співвідношення мас між вегетативними та генеративними органами, характеру донорноакцепторних відносин у рослинах вплинули на продуктивність культур. Гіберелова кислота збільшує кількість плодів у рослин перців і томатів на $33 \%$ та $26 \%$, що збільшує урожайність культур відповідно на $28 \%$ та $30 \%$. Тебуконазол збільшує кількість плодів у перців і томатів на $14 \%$ і 21\%, що сприяло збільшенню урожайності відповідно на 22\% та $12 \%$ (табл. 4).

\section{Таблиця 3}

Вплив регуляторів росту на вміст суми вуглеводів (цукри + крохмаль) у вегетативних органах рослин перців і томатів у фазу плодоношення (\% на суху речовину, середні дані за 2013-2014 роки, n= 5)

\begin{tabular}{|c|c|c|c|c|c|c|}
\hline \multirow{2}{*}{ Показники } & \multicolumn{3}{|c|}{ Перці } & \multicolumn{3}{|c|}{ Томати } \\
\hline & K & $\Gamma K_{3}$ & EW-250 & $\mathrm{K}$ & $\Gamma K_{3}$ & EW-250 \\
\hline Коріння & $5,96 \pm 0,12$ & $5,76 \pm 0,11$ & $5,25 \pm 0,12 *$ & $4,51 \pm 0,09$ & $4,54 \pm 0,10$ & $6,84 \pm 0,15^{*}$ \\
\hline Стебло & $11,89 \pm 0,29$ & $11,31 \pm 0,26$ & $11,15 \pm 0,27 *$ & $6,65 \pm 0,17$ & $6,65 \pm 0,17$ & $6,03 \pm 0,14^{*}$ \\
\hline Листя & $13,37 \pm 0,32$ & $12,81 \pm 0,28$ & $12,39 \pm 0,33$ & $10,08 \pm 0,27$ & $9,58 \pm 0,24$ & $10,20 \pm 0,28$ \\
\hline
\end{tabular}

Примітка: позначення див. табл. 1 .

\section{Таблиця 4}

Вплив регуляторів росту на урожайність рослин перців і томатів (середні дані за 2013-2015 роки, n = 5)

\begin{tabular}{|c|c|c|c|c|c|c|}
\hline \multirow{2}{*}{ Показник } & \multicolumn{3}{|c|}{ Перці } & \multicolumn{3}{|c|}{ Томати } \\
\hline & $\mathrm{K}$ & $\Gamma K_{3}$ & EW-250 & $\mathrm{K}$ & $\Gamma K_{3}$ & EW-250 \\
\hline Кількість плодів на рослині, шт. & $5,89 \pm 0,232$ & $7,85 \pm 0,381^{*}$ & $6,73 \pm 0,320^{*}$ & $10,01 \pm 0,483$ & $12,60 \pm 0,611^{*}$ & $12,14 \pm 0,572^{*}$ \\
\hline Середня маса одного плоду, г & $88,1 \pm 4,24$ & $83,4 \pm 3,98$ & $90,2 \pm 4,44$ & $152,6 \pm 7,14$ & $159,5 \pm 7,47$ & $161,1 \pm 7,92$ \\
\hline Урожайність плодів, т/га & $32,9 \pm 1,57$ & $42,2 \pm 2,04 *$ & $40,0 \pm 1,89 *$ & $53,4 \pm 2,54$ & $69,6 \pm 3,44 *$ & $67,8 \pm 3,35^{*}$ \\
\hline
\end{tabular}

Примітка: позначення див. табл. 1 .

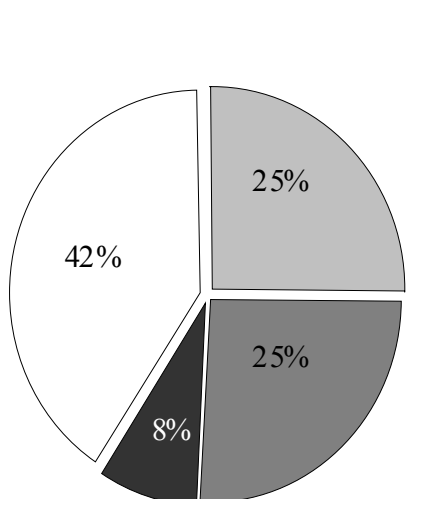

Контроль

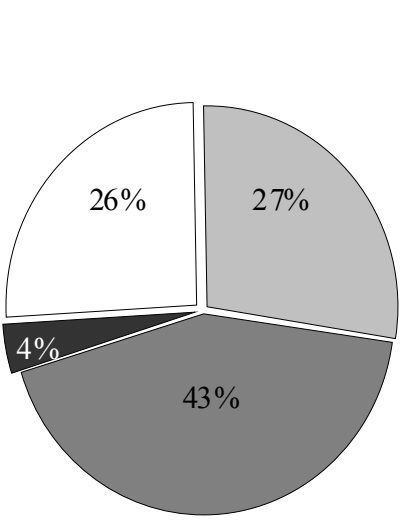

Контроль

Перець

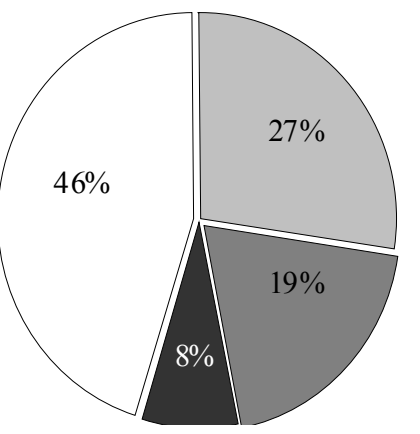

Гіберелова кислота

Томати

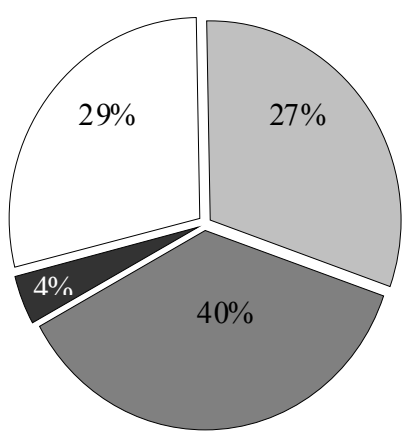

Гіберелова кислота

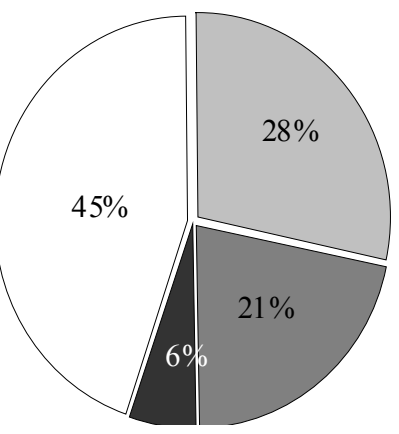

Тебуконазол

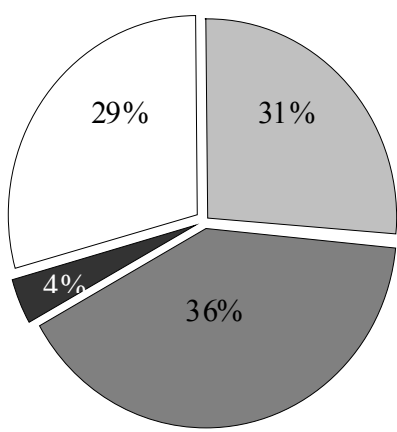

Тебуконазол

Рис. Вплив гіберелової кислоти та тебуконазолу на співвідношення маси сухої речовини органів перців і томатів (фаза утворення плодів): біле - плоди; світло-сіре - листки; темно-сіре - стебло; чорне - коріння; * - різниця за $\mathrm{P}<0,05$

\section{Обговорення}

Ключову роль у продуктивності рослин відіграє фотосинтетична активність, яка великою мірою визначається площею листкової поверхні, кількістю та тривалістю життя листків, мезоструктурою листка. Дослідження останніх років свідчать, що регуляція ростових процесів рослин за допомогою фітогормонів і ретардантів різних класів супроводжується суттєвими 
змінами морфогенезу, які стосуються формування різних рівнів організації фотосинтетичного апарату рослин (Kuryata and Polyvanyj, 2015; Kuryata and Poproc'ka, 2016). Зважаючи на суттєві морфологічні аспекти дії стимуляторів та інгібіторів росту рослин, застосування цих груп препаратів дозволяє з'ясувати значення анатомо-морфологічної та мезоструктурної складових у реалізації донорно-акцепторних відносин рослини та оптимізації продукційного процесу.

Отримані нами результати свідчать, що як гіберелін, так i антигібереліновий препарат тебуконазол стимулювали формування та функціонування фотосинтетичного апарату перцю солодкого та томатів їстівних, однак шляхи цієї регуляції різні. Посилення фотосинтетичної активності рослин за дії гібереліну визначалося у першу чергу формуванням більшої кількості листків і загальної площі листкової поверхні. Застосування ретарданту тебуконазолу зумовлювало суттєву перебудову мезоструктури листків: листки потовщувалися за рахунок розростання ключової фотосинтетичної тканини - хлоренхіми. Відбувалося збільшення об'єму клітин стовпчастої асиміляційної паренхіми та лінійних розмірів клітин губчастої паренхіми листків. При цьому підвищується питома поверхнева щільність листків, суттєво зростає вміст хлорофілів та вміст азоту (у першу чергу білкового) порівняно з контролем і варіантом із застосуванням гібереліну. Така глибока перебудова фотосинтетичного апарату рослини викликала суттєве зростання донорної функції листків перцю та томатів за дії тебуконазолу. Показник цього - зростання чистої продуктивності фотосинтезу (найвищої серед усіх варіантів досліду). Отримані результати свідчать також про те, що збільшення хлорофільного індексу фітоценозу виявилося вагомішим фактором, ніж збільшення листкового індексу. Зокрема, у томатів за дії тебуконазолу листковий індекс нижчий, ніж у контролі, однак завдяки високому показнику хлорофільного індексу урожайність насаджень збільшувалася. Зростання листкового індексу в агроценозі - не завжди позитивний фактор біопродуктивності, оскільки загущення посівів, формування надмірної листкової поверхні може спричинити затінення сусідніх рослин, i, як наслідок, зумовити зменшення урожайності культури. Результати нашого дослідження свідчать, що застосування гібереліну та тебуконазолу не викликало таких негативних наслідків. Навпаки, відбувалося зростання урожайності культур у дослідних варіантах.

Один із найпотужніших акцепторів асимілятів - процеси вегетативного росту та ріст плодів (карпогенез). Оскільки у період плодоношення витрати асимілятів на процеси росту вегетативних органів суттєво зменшуються, оптимізація фотосинтетичного апарату рослин перцю та томатів викликала закладання більшої кількості плодів на рослині та підвищення урожайності культур. Аналіз співвідношення мас вегетативних органів і плодів дослідних рослин свідчить, що масова частка плодів (акцепторна сфера рослини у період плодоношення) за дії обох препаратів зросла. При цьому в обох варіантах досліду вищою була також масова частка донорів асимілятів - листків. Крім основного джерела асимілятів - процесів фотосинтезу, які посилюються внаслідок формування більшої площі листкової поверхні (варіант із гібереліном), або оптимізації мезоструктури (варіант із тебуконазолом), ймовірно формування та ріст плодів відбуваються частково за рахунок реутилізації вуглеводів із вегетативних органів рослини на процеси карпогенезу. Зокрема, у перцю солодкого у період росту плодів відбувалося зменшення вмісту суми вуглеводів у всіх вегетативних органах. У томатів достовірне зменшення вмісту вуглеводів відмічалося лише в стеблі.

Отже, застосування у період бутонізації гіберелової кислоти та ретарданту тебуконазолу сприяє підвищенню продуктивності рослин перцю солодкого та томатів унаслідок оптимізації структури та функціонування листкового апарату рослин.

\section{Висновки}

Оптимізація продукційного процесу рослин перцю солодкого та томату їстівного за дії гіберелової кислоти і тебуконазолу реалізується через посилення донорного потенціалу рослин унаслідок морфологічних і мезоструктурних змін листкового апарату. За дії гіберелової кислоти зростає кількість листків та їх сумарна площа на рослині, а за дії тебуконазолу відбувається перебудова мезоструктури листків, формування потужнішої хлоренхіми, збільшення вмісту хлорофілів, сумарного та білкового азоту в них, що є важливою передумовою інтенсифікації фотосинтетичних процесів.

\section{References}

Bala, M., Gupta, S., Gupta, N. K., \& Sangha, M. K. (2013). Practicals in plant physiology and biochemistry. Scientific Publishers, Jodhpur.

Khan, A. L., Hamayun, M., Kang, S. M., Kim, Y. H., Jung, H. Y., Lee, J. H., \& Lee, I. J. (2012). Endophytic fungal association via gibberellins and indole acetic acid can improve plant growth under abiotic stress: An example of Paecilomyces formosus LHL10. BMC Microbiology, 12(1), 3.

Kumar, S., Ghatty, S., Satyanarayana, J., \& Guha, A. (2012). Paclobutrazol treatment as a potential strategy for higher seed and oil yield in fieldgrown Camelina sativa L. Crantz. BSK Research Notes, 5, 1-13.

Kuryata, V. G., Rohach, V. V., Rohach, T. I., \& Khranovska, T. V. (2016). The use of antigibberelins with different mechanisms of action on morphogenesis and production process regulation in the plant Solanum melongena (Solanaceae). Visnyk of Dnipropetrovsk University. Biology, Ecology, 24(1), 230-234.

Matysiak, K., \& Kaczmarek, S. (2013). Effect of chlorocholine chloride and triazoles - tebuconazole and flusilazole on winter oilseed rape (Brassica napus var. oleifera $\mathrm{L}$.) in response to the application term and sowing density. Journal of Plant Protection Research, 53(1) 79-88.

Mohammad, N. K., \& Mohammad, F. (2013). Effect of GA3, N and P ameliorate growth, seed and fibre yield by enhancing photosynthetic capacity and carbonic anhydrase activity of linseed. Integrative Agriculture, 12(7), 1183-1194.

Muhammad, I., \& Muhammad, A. (2013). Gibberellic acid mediated induction of salt tolerance in wheat plants: Growth, ionic partitioning, photosynthesis, yield and hormonal homeostasis. Environmental and Experimental Botany, $86,76-85$.

Panyapruek, S., Sinsiri, W., Sinsiri, N., Arimatsu, P., \& Polthanee, A. (2016) Effect of paclobutrazol growth regulator on tuber production and starch quality of cassava (Manihot esculenta Crantz). Asian Journal of Plant Sciences, 15(1-2), 1-7.

Pavlista, A. D. (2013). Influence of foliar-applied growth retardants on russet burbank potato tuber production. American Journal of Potato Research, 90, 395-401.

Pobudkiewicz, A. (2014). Influence of growth retardant on growth and development of Euphorbia pulcherrima Willd. ex Klotzsch. Acta Agrobotanica, 67(3), 65-74.

Poprotska, I. V., \& Kuryata, V. G. (2017). Features of gas exchange and use of reserve substances in pumpkin seedlings in conditions of skoto- and photomorphogenesis under the influence of gibberellin and chlormequatchloride. Regulatory Mechanisms in Biosystems, 8(1), 71-76.

Ribeiro, D. M., Araújo, W. L., Fernie, A. R., Schippers, J. H. M., \& MuellerRoeber, B. (2012). Translatome and metabolome effects triggered by gibberellins during rosette growth in Arabidopsis. Journal of Experimental Botany, 63(7), 2769-2786

Rogach, V. V., \& Rogach, T. I., 2015. Vplyv syntetychnyh stymuljatoriv rostu na morfofiziologichni harakterystyky ta biologichnu produktyvnist' kul'tury kartopli. Visnyk of Dnipropetrovsk University. Biology, Ecology, 23(2), 221-224 (in Ukrainian).

Rogach, V. V., Poprotska, I. V., \& Kuryata, V. G. (2016). Diya giberelinu ta retardantiv na morfogenez, fotosyntetychnyj aparat i produktyvnist' kartopli [Effect of gibberellin and retardants on morphogenesis, photosynthetic apparatus and productivity of the potato]. Visnyk of Dnipropetrovsk University. Biology, Ecology, 24(2), 416-419 (in Ukrainian).

Saeidi-Sar, S., Abbaspour, H., Afshari, H., \& Yaghoobi, S. R. (2013). Effects of ascorbic acid and gibberellin $\mathrm{A} 3$ on alleviation of salt stress in common bean (Phaseolus vulgaris L.) seedlings. Acta Physiologiae Plantarum, 35(3), 667-677.

Sardoei, A. S., Yazdi, M. R., \& Shshdadneghad, M. (2014). Effect of cycocel on growth retardant cycocel on reducing sugar, malondialdehyde and other aldehydes of Cannabis sativa L. International Journal of Biosciences, 4(6), 127-133. 
Sugiura, D., Sawakami, K., Kojim, M., Sakakibara, H., Terashima, I., \& Tateno, M. (2015). Roles of gibberellins and cytokinins in regulation of morphological and physiological traits in Polygonum cuspidatum responding to light and nitrogen availabilities. Functional Plant Biology, 42(4), 397-409.

Sukul, A., Sukul, N. C., Sen, P., Bhattacharya, A., \& Sukul, S. (2014). Homeopathic potencies alter photosynthesis of cowpea. Homeopathy, 103(1), 91-92.

Tae-Yun, K., \& Jung-Hee, H. (2012). Effects of hexaconazole on growth and antioxidant potential of cucumber seedlings under UV-B radiation. Journal of Environmental Science International, 21(12), 1435-1447.

Van Emden, H. F. (2008). Statistics for terrified biologists. Blackwell, Oxford.

Wang, X., Han, F., Yang, M., Yang, P., \& Shen, S. (2013). Exploring the response of rice (Oryza sativa) leaf to gibberellins: A proteomic strategy. Rice, 6(1), 17.

Wang, Y., Gu, W., Xie, T., Li, L., Sun, Y., Zhang, H., Li, J., \& Wei, S. (2016). Mixed compound of DCPTA and CCC increases maize yield by improving plant morphology and up-regulating photosynthetic capacity and antioxidants. Plos One, 11(2), e0149404.
Yan, W., Yanhong, Y., Wenyu, Y., Taiwen, Y., Weiguo, L., \& Wang, X. (2013). Responses of root growth and nitrogen transfer metabolism to uniconazole, a growth retardant, during the seedling stage of soybean under relay strip. Communications in Soil Science and Plant Analysis Intercropping System, 44(22), 3267-3280.

Yan, Y., Wan, Y., Liu, W., Wang, X., Yong, T., \& Yang, W. (2015). Influence of seed treatment with uniconazole powder on soybean growth, photosynthesis, dry matter accumulation after flowering and yield in relay strip intercropping system. Plant Production Science, 18(3), 295-301.

Yang, L., Yang, D., Yan, X., Cui, L., Wang, Z., \& Yuan, H. (2016). The role of gibberellins in improving the resistance of tebuconazole-coated maize seeds to chilling stress by microencapsulation. Scientific Reports, 60, 1-12.

Yu, S. M., Lo, S. F., \& Ho, T. D. (2015) Source-sink communication: Regulated by hormone, nutrient, and stress cross-signaling. Trends in Plant Science, 20(12), 844-857.

Zhang, W., Xu, F., Hua, C., \& Cheng, S. (2013). Effect of chlorocholine chloride on chlorophyll, photosynthesis, soluble sugar and flavonoids of Ginkgo biloba. Notulae Botanicae Horti Agrobotanici Cluj-Napoca, 41(1), 97-103. 